\title{
CUSTOMER LOYALTY MODEL: A CUSTOM PRODUCT PERSPECTIVE, INNOVATION ADAPTION, BRAND IMAGE, LIFESTYLE, AND TRUST IN THE INTERIOR FURNITURE INDUSTRY
}

\author{
Feno Candri" ${ }^{*}$, Syahmardi Yacob ${ }^{2}$, Junaidi ${ }^{3}$, Tona Aurora Lubis ${ }^{4}$ \\ 1. Student at the doctoral program, Economic Faculty, Universitas Jambi \\ 2,3,4 Lectures at Doctoral Program in Economics, Jambi University
}

\begin{abstract}
Custom Interior Furniture is a product made and produced based on consumers' demands. It has become a new phenomenon where customers are now more interested in a product representing owners' hopes and desires. It indeed cannot be separated from the patterns and lifestyles of people who are increasingly open in accepting the development of information technology, where access to information about interior design furniture is straightforward to obtain. Therefore, it makes a new trend rapidly influencing the paradigm of modern society today about interior design, especially custom interior furniture products. This study uses a Literature Review approach which reviews and discusses a series of Custom Products with references from existing articles. The selected variables are Custom Products, Innovation Adaption, Brand Image, Life Style, Trust, and Customer Loyalty.
\end{abstract}

Keywords: Custom Products, Innovation Adaption, Brand Image, Live Style, Trust, and Customer Loyalty

\section{INTRODUCTION}

In the world of products, there are 2 (two) types of products, namely mass products and custom products. Along with the development of the times and technology, consumers are more open and understand more about the quality of a product. Nowadays, consumers are more interested in custom products made and designed according to the consumers' wishes. A custom product or customization system uses technology to form flexible processes within the organizational structure to provide various products and services that meet the specific needs of customers or individuals. (Da Silveira et al., 2001).

This customization requires sensitivity and foresight from service providers in reading market opportunities and potential, where the needs of each customer or individual are different. Hence, capturing customer desires and expectations is the most critical thing. In custom Interior Furniture products, the ability of a service provider or company to understand the wishes of customers is one of the determinants of customers in making decisions about who or which company they will use to carry out their work to match their expectations desires. Trustor customer trust is an important point that must be owned by companies or service providers to continue to exist in the business world of Custom Interior Furniture Products. Trust is a willingness to rely on the ability, integrity, and motivation to act to serve the needs and interests that have been agreed upon, implicitly or explicitly (Westall, 2012). Distinctive characteristics products are passive users, but consumers provide ideas related to the desired 
design concept so that what is expected will be realized properly and directed. The level of customer satisfaction for custom interior furniture products will depend on the results of the products produced, where the quality of work quality, timeliness, and commitment are benchmarks for the(Faircloth et al., 2001)e sustainability of the company or product and service provider. It is essential to maintain the quality and quality of work, which is a must that must be maintained and prioritized as a condition to be able to exist in the world of custom interior furniture products. Trustor trust is highest, affecting repeat sales or customer loyalty. From the above statement, we assume that the solution to this problem is one of custom interior furniture products, in this case, of course, in the field of design. Likewise,(B. Joseph Pine II Don Peppers, 1995) assert that "Customers, whether consumers or businesses, do not want more choices, they want what they want, when, where, and how they want it" (p. 103). The hallmark of custom product customers is that they tend not to bother. However, they are very observant with the results and quality of work because the high cost is not a problem as long as the results obtained can be satisfactory and follow their wishes. Customize is very different from mass products, where custom products are made limited or limited because they are adjusted to the wants and desires of each consumer so that the results obtained will never be the same between one customer and another. Several variables are considered to determine a custom product in terms of custom products. Custom products are a favorite choice for the middle class and above to bring the desired atmosphere to their dwelling. With a concept based on their wishes, the interior furniture products can genuinely present a pleasant atmosphere.

\section{Custom Products}

\section{LITERATURE REVIEW}

(Faircloth et al., 2001) said that custom products referred to a concept offered to consumers in terms of aesthetics. It is usually applied to a building or space of a house, restaurant, cafe, and public area by aligning the ideas and desires of the owner or consumer (Santoso 2013). a product made specifically based on customer orders or wishes, which will also be adapted to existing conditions in the field. "Products are everything that is offered to the market to satisfy human wants or needs" (Kottlet \& Keller $(2012 ; 40)$. Custom products are improvements of service to consumers so that the products obtained are of higher quality and different from existing mass products. With the concept of making a product according to your wishes, consumers can serve customers at a more exclusive stage.

The consumers or customers of custom products are the upper-middle class, where the cost to get the product issued is greater than the cost of standard products on the market. It is undoubtedly a difference in quality and service provided to customers; quality and service will be a benchmark for consumers or customers to make further or repeated purchases. Custom Product's characteristics focus on more quality requirements than the product cost itself. Custom interior furniture products have features that cannot be found in standard products on the market, such as unique, elegant, and different design models to display the luxurious and luxurious side of the interior furniture product. The results of custom products can interpret the owner in terms of character, hobbies, and the consumer's class. Self-adjustment occurs when customers choose their attributes from a special menu for the form of offering that best suits their needs (Park \& Yoo, 2018)Ghosh et al., 2006). This statement illustrates that consumers or customers of custom products will be actively involved in the initial job design process so that the results will follow their wishes and expectations. Direct involvement of consumers or customers distinguishes it from mass products where consumers cannot choose or determine the design form. However, consumers or customers must adapt the product to their environmental conditions.

A study conducted in South Korea explored the impact and benefits of mass-adjusted products on emotional product engagement, favorable attitudes towards mass customization programs, and 
sustained effects on loyalty intentions. The results of this study reveal that perceived benefits positively affect emotional product attachment and attitudes towards mass customization programs. In addition, attachment positively affects attitudes, which affects loyalty intentions. The study also found benefits, devotion, attitudes, and preferences of highly engaged consumers (high-fashion innovators) than less engaged consumers (low-fashion innovators). This study concludes with theoretical and practical implications for mass customization programs (Park \& Yoo, 2018). Consumers who have the financial ability will tend to choose custom products because the results obtained will be more satisfying, and the quality of the material will be more guaranteed.

\section{Innovation Adaption}

In the world of custom products, design innovation will refer to adopting a concept desired by consumers. The idea is a novelty that refers to the product innovation made. Authenticity values on Sacred objects are limited to material heritage, which contains tangible values such as form, function, construction of architectural things, materials, details, and non-material environmental matters, such as the sacrum, symbols, memory, and historical and social issues (Pierscionek, 2019). In designing an interior furniture design concept, it is necessary to understand the meaning desired by consumers in the product to be made. It takes flexibility and the ability to understand the desires of consumers who keep up with the times so that the results of custom interior products still have high artistic value but can accommodate consumer desires by adopting a role model that has been innovated. Providing customized products with customer satisfaction has become an inevitable trend for modern enterprises that can be customized to stay competitive. (Li et al., 2014). Innovation and adoption is a strategy to survive in the world of custom interior furniture products, where a concept is needed to produce work that matches the expectations and desires of consumers. Innovation and adaptation can be born from experience and thought experienced by consumers so that hopes and desires will be in harmony with a design concept that can reflect the owner's character and nature. It is necessary to survive in custom interior furniture products if a designer cannot innovate and adopt consumer desires.

Furthermore, we provide insight into consumer market segments for companies seeking a strategic fit for more effective customization. According to a study conducted across several studies, latent cluster analysis was used to profile customization requests. As a result, four distinct segments were identified: Non-Customizer, New Customizer, Active Customizer, and Lapsing Customizer while studying the considerations of their results in terms of new product designs. The various patterns of customization preferences and consumption patterns between segments provide an opportunity for retail and service providers to target customized offerings more effectively (Pallant et al., 2020). From observations of this research, it can be seen that innovation and adoption have opportunities for customization. Adoption of innovation is needed in custom interior furniture products, where innovation will present a concept that will attract consumer buying interest. Adoption innovation by introducing concepts that keep up with the times will be the main attraction.

\section{Brand Image}

Brand Image is one of the company's identities, which can describe its condition, it's big-name related to its products. Brand Image is constantly evolving along with the quality of the products produced. Consumers always remember a company's brand when products delivered are by customer expectations and desires. Information obtained by consumers regarding the company or service provider profile will play an essential role for a company or individual in obtaining and determining the best company as the executor of the work desired by consumers or company and individual customers. Many studies have been conducted related to Brand Image, all of which are evidence that Brands determine the mindset of consumers in finding and deciding which company to partner with. Perceived incongruence between brand image and product form induces ambiguity regarding that brand image, 
thereby thwarting the formation of impressions on the brand and thus negatively impacting consumer preferences (Van Rompay \& Pruyn, 2008). As a result, consumers will prefer products with physical forms that align with the brand image. This argument is in line with the literature on comparative effects in advertising, which suggests that alignment between spokesperson and product characteristics enhances consumer attitudes toward the advertised product environment (Till \& Busler, 2000).

Promotions carried out by the company will have a positive impact on the brand so that the public widely knows it. In addition to promotional advertisements on social media, the natural quality of products and consumer satisfaction will also make the brand widely known in the community. Many large companies are starting from small; due to good product quality, their brand image is slowly being lifted, along with the high level of consumer confidence in their products. This is clear proof that Brand Image will always be the first consideration for consumers so that the products they get will not disappoint. Consumers with more minor creative mindsets tend to adopt a conventional approach, thus focusing on familiar and closely related constructs in their associative network while avoiding rarely linked constructs (Cropley, 2006). The traditional consumer model seeks information related to a company's Brand Image through person-to-person or relationship-to-relationship transmission. Meanwhile, creative consumers will be more rational in searching for information via the internet, social media, and rating companies in the existing area.

(Warayuanti \& Suyanto, 2015), brand image is a collection of associations about a brand stored in consumers' minds or memories. Several factors influence brand image, according to Schiffman \& Kanuk, as follows: 1. Quality is related to the quality of goods offered by manufacturers with specific brands. 2. To be trusted or relied upon. They relate to opinions or agreements formed by the community about a consumed product. 3. Usefulness or benefits related to the function of a product that consumers can utilize. 4. Price, which in this case is related to the high or low or the amount of money spent by consumers to influence a product, can also be influenced by long-term image. 5. The brand itself owns the image, namely in views, agreements, and information relating to a particular product brand.

According to Keller (2000), brand image is the consumer's perception of the product's brand image consumed or used. According to Keller (2000), brand image measurement can be done based on aspects of a brand, namely: 1 . The brand is easy to remember, meaning that the selected brand elements should be easy to remember and mention or pronounce. Symbols, logos, and names should be attractive and unique to attract the attention of customers or the public to be placed and consumed. 2. Brands are easily recognizable; apart from the logo, a brand will be recognized through the message and how the product is packaged and presented to consumers, which is called a trade dress. Through intensive communication, a particular product will be easily recognized by consumers. So that trade dress is often the same as a trademark, namely the differentiation of products and services in the market that can be requested for legal protection. 3. Good brand reputation; for the company, the brand image means the public's perception of the company's identity. This perception is based on what the public knows or thinks about the company in question. The same company does not necessarily have the same image in customers' eyes. Company image is one of the determinants of consumers or customers in deciding.

Schiffman \& Kanuk (2007), brand image is a collection of associations about a brand stored in consumers' minds or memories. Several factors influence brand image, according to Schiffman \& Kanuk, as follows: 1. Quality is related to the quality of goods offered by manufacturers with specific brands. 2. To be trusted or relied upon. It relates to opinions or agreements formed by the community about a consumed product. 3. Usefulness or benefits related to the function of a product that consumers can utilize. 4. Price, the number of money consumers spend to influence a product, can also be influenced by the long-term image. 5 . The brand itself owns the image, namely in views, agreements, and information relating to a particular product brand.

Keller (2000) brand image consists of two main factors, namely:1. Physical factors are the physical characteristics of the brand, namely: design, packaging, logo, brand name, function, and product use of 
the brand. 2. Psychological factors, formed by emotions, beliefs, values, and personality that consumers consider describing the brand's product. Brand image is closely related to what people think and feel about the brand, so the brand image psychological factors play more role than the physical factors of a particular brand.

(Supriadi \& Putri, 2020) stated that a brand image is holistic for all brand associations. Brand image is an essential aspect of the brand; it can be based on reality or fiction, depending on how the customer perceives it. And to measure brand image can be associated with service quality. Tipton (2011:112), brand image or description describes consumer associations and beliefs about specific brands. Several quantitative and qualitative techniques have been developed to help reveal consumer association perceptions of a particular brand, including multidimensional scaling, projection techniques, and so on. The analysis results show that experiential marketing on customer satisfaction and customer's brand loyalty has a positive influence. (Syahmardi et al., 2017)

\section{LifeStyle}

LifeStyle is a lifestyle owned by each individual, significantly affecting taste and character. In this world of customization, it will determine which level the consumer is at so that the desired quality can be determined. In custom interior furniture products, lifestyle has the top role in determining the concept and design, where consumers tend to want an idea that can represent the character. These characteristics reflect the lifestyle of the consumer itself. A comparative study of Korean and Japanese Traditional Furniture Design based on residential behavior related to floor seating demonstrates the character of the furniture and the nature of the interior space, a cultural symbol representing the character of the era and region. (Kim \& Choi, 2003)(Kim \& Choi, 2003). Many factors must be considered in building a design concept for custom products. It could be the quality of materials, habits, lifestyle, desires, and expectations. A person's lifestyle will provide a picture of the consumer himself to determine what kind of concept he wants. In custom products, the process is very different from mass products, where the process is carried out in detail, from the design process to the production process. LifeStyle describes the lifestyle of consumers and determines their perspective on a product that is produced, where the quality of materials and work is very concerned by the significant costs incurred. The interior design creates and coordinates elements within various structures (Tarafder, 2019). The means-end theory shows the method of personal values that influence individual behavior. It is a research method derived from the cognitive structure of consumers after years of development. This theory has been widely used in the field of marketing. The end-of-the-way theory model has three levels. The top one is personal value. Different types of interests lie at a moderate level. The bottom is the product attributes. This shows an indirect and profound relationship between personal values and product attributes. This study explores the relationship between unique lifestyles and product attributes. Mainly how the theory is applied to furniture design and development; based on this theory, designers design new furniture collections. These products have been produced and displayed in international exhibitions. (Zhang et al., 2017). The brand is an important factor determining the world of custom products, where consumers will care about a brand they will buy. Consumers will see how the brand of goods they buy will affect their strata where consumers of custom products are the middle class. Lifestyle has a significant influence in determining what kind of design concept consumers want for custom products. Consumers want the custom interior furniture product they produce to be a concept they want, so they are willing to pay a high price.

\section{Trust}

(Guo et al., 2018) said that is an essential prerequisite for corporate Cooperation. Trust occupies the first position in Cooperation between service providers and consumers; the association will be established and implemented if consumers believe in the ability and commitment of the company or product and service provider in managing the work that consumers or customers will submit. Without 
consumers' trust, the Cooperation between service providers and customers will not be realized and implemented. The importance of faith is the primary basis for consumers in determining whether the company can be trusted and can carry out the mandate of the work to be submitted. Trust is a human psychological state (Twyman et al., 2008) and can benefit individuals, teams, and organizations (Dirks \& Ferrin, 2002). Trust is established when a consumer's psychology is satisfied. The approach that brand trust arises through the process of thinking (cognitive) and feeling (affective) (Morrow, Hansen \& Pearson, 2004; Srivastava, Dash, \& Mookerjee, 2015). Cognitive beliefs are driven by knowledge and rational thought processes, whereas affective beliefs are driven by feelings and emotional exchanges (Albert \& Merunka, 2013; Dowell, Morrison, \& Heffernan, 2015; Johnson \& Grayson, 2005). The consumer's thought process also influences trust through feelings in determining and deciding the conclusions of a personal assessment of prospective companies providing products and services. Although most studies found consistent results, factors influence the development of cognitive and affective beliefs (Dowell et al., 2015; Johnson \& Grayson, 2005; Lee, Lee, \& Tan, 2015; Sekhon, Roy, Shergill, \& Pritchard, 2013). They also give little consideration to the role of other essential factors between consumer-to-consumer relationships - such as the influence of friends in this consideration process. Despite peers' critical role in shaping consumer beliefs (Pechmann \& Knight, 2002).

Lack of and limited information regarding recommendations from others can affect consumers' cognitive and affective levels of trust in brands, especially when consumers can be vulnerable due to lack of information and previous negative experiences (e.g., Frank, Enkawa, \& Schvaneveldt, 2015; Haji, 2014). Existing information related to the brand of the service provider company will be a source of information for consumer consideration about the trust that will be submitted. Accordingly, the issue that affects the marketing force for a company is related to the perception of completing the work that consumers have submitted to the company; how the company's commitment will be a list of considerations in making decisions. In addition to the influence of the company name and relationship with consumers, the relationship between consumers will affect the evaluation of the company name (Balmer, 1998; Hudson, Huang, Roth, \& Madden, 2015). A good relationship between the shift relation will also affect consumers believing that the service provider company can manage the work submitted with a high commitment. Trust relates to the trustee's willingness to engage in a vulnerable relationship by expecting positive behavior and intentions from the confidant (Melewar et al., 2017). Personal trust is justified in personal relationships, such as national brands and system trust, embedded in institutions (Ozdemir et al., 2020).

\section{Customer Loyalty}

According to Ali Hasan (2008; 83), Customer loyalty is defined as people who buy, especially those who believe regularly and repeatedly. While Gremler and Brown (in Ali Hasan, 2008:83) state that customer loyalty is a customer who repurchases an item or service and has a positive commitment and attitude towards service companies, for example, by recommending others to buy. Griffin (in Diah Dharmayanti, 2006: 38) argues that loyal customers are satisfied with certain products and services, so they are enthusiastic about introducing them to others. Engel, Blackwell, Miniard (in Ali Hasan, 2008:84) say customer loyalty is the habit and behavior of repeat purchases, high relevance, and involvement in the choice, characterized by seeking external information and evaluating alternatives. According to Amin Widjaja Tunggal (2008), is customer attachment to a brand, store, manufacturer, service provider, or other entity based on a favorable attitude and reasonable response. And perspectives on customer loyalty. Loyalty is a buying behavior response that decision-makers can continuously reveal by paying attention to alternative brands from several similar brands and is a function of psychological processes. Customer loyalty includes feelings and does not involve affective factors (Dharmesta, in Diah Dharmayanti 2006:37-38). Olson (in Trisno Mushanto, 2004 128) argues that 
customer loyalty is a behavioral impulse to make purchases repeatedly and build customer loyalty to a product or service produced by the business entity, which takes a long time through a buying process, which happens often.

According to Kottler \& Keller (2007: 175), loyalty or loyalty is defined as a firmly held commitment to buy or repeat certain products or services in the future despite situational influences and marketing efforts that have the potential to cause behavior change. According to Kotler (2005:178), "The long-term success of a particular brand is not based on the number of consumers who purchase it only once, but on the number who become repeat purchases." Therefore, it was concluded that loyal consumers are not measured by how much they buy but by how often they make repeat purchases, including recommending others to buy. We also find that loyalty and satisfaction have a reciprocal relationship in that each positively reinforces the other, and this relationship between happiness and overall loyalty is further strengthened online. (Shankar et al., 2003).

\section{DISCUSSION}

This theoretical framework that will be developed in this research refers to the description and review of various literature that has been carried out in the previous sub-chapter. This research model consists of 4 (four) variables that are used to explain "Customer Loyalty Model: A Perspective from Custom Products, Innovation Adoption, Brand Image, Life Style and Trust in the Interior Furniture Industry." This aims to examine the perspective of Product Custom Variables, Initiative Adaption, Brand Image, Life Style and Trust on Customer Loyalty. Based on the proposed literature review results, the paradigm and concept of thinking from the research "Customer Loyalty Model: A Perspective from Custom Products, Innovation Adaption, Brand Image, Life Style and Trust in the Interior Furniture Industry."

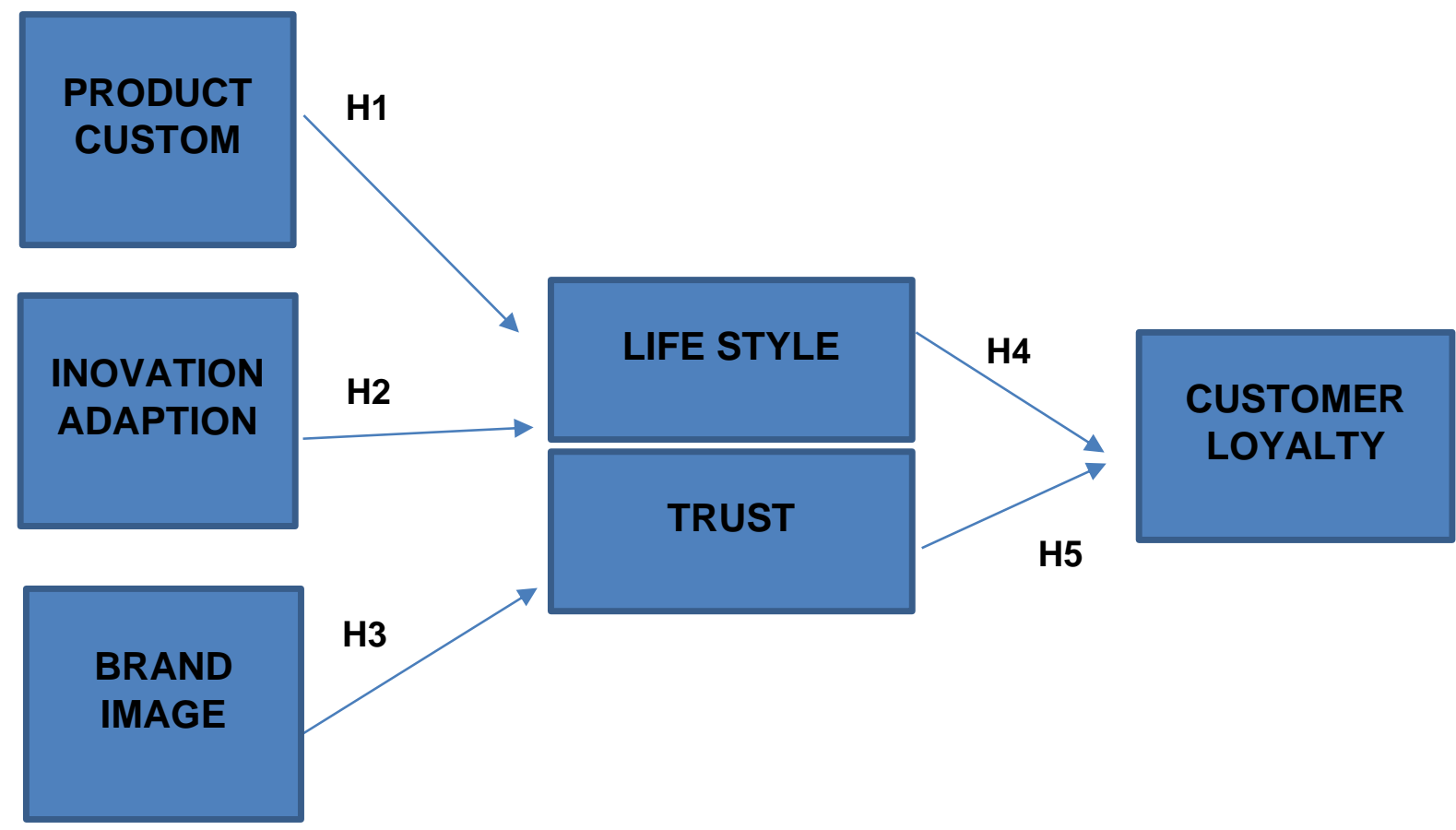

\section{Research Hypothesis}

H1: Product Custom (PS) has a positive effect on Customer Loyalty (CL) through LifeStyle (LS) and Trust (T) 
H2: Innovation Adaption (IA) has a positive effect on Customer Loyalty (CL) through LifeStyle (LS) and Trust $(\mathrm{T})$

H3: Brand Image (BI) has a positive effect on Customer Loyalty (CL) through LifeStyle (LS) and Trust (T)

H4: LifeStyle (LS) has a positive effect on Customer Loyalty (CL)

H5: Trust (T) ) has a positive impact on Customer Loyalty (CL)

\section{CONCLUSION}

From the explanation of the hypothesis described above, it can be concluded that Custom Products, Innovation Adaption, Brand Image, Life Style, Trust are very influential on Customer Loyalty as Independent, Dependent, and Intervening Variables. Custom products are very much determined by the variables above. These variables illustrate Innovation Adaption, Brand Image, Life Style, Trust, which is a unit that must be considered to survive in the world of custom interior furniture products. Innovation in the form of adaptation that refers to lifestyle must be carried out so that the Brand Image can be maintained, which will later impact consumer trust as the target of customer loyalty.

\section{REFERENCES}

B. Joseph Pine II, Don Peppers, and M. R. (1995). Do You Want to Keep Your Customers Forever? Harvard Business Review. https://hbr.org/1995/03/do-you-want-to-keep-your-customers-forever

Cropley, A. (2006). In praise of convergent thinking. Creativity Research Journal, 18(3), 391-404. https://doi.org/10.1207/s15326934crj1803_13

Da Silveira, G., Borenstein, D., \& Fogliatto, F. S. (2001). Mass customization: Literature review and research directions. International Journal of Production Economics, 72(1), 1-13. https://doi.org/10.1016/S0925-5273(00)00079-7

Faircloth, J. B., Capella, L. M., \& Alford, B. L. (2001). The Effect of Brand Attitude and Brand Image on Brand Equity. Journal of Marketing Theory and Practice. https://doi.org/10.1080/10696679.2001.11501897

Guo, R., Zhang, W., Wang, T., Li, C. B., \& Tao, L. (2018). Timely or considered? From a legitimacy perspective, brand trust repair strategies and mechanisms after greenwashing in China. Industrial Marketing Management, 72(July 2017), 127-137. https://doi.org/10.1016/j.indmarman.2018.04.001

Kim, J., \& Choi, K. (2003). Comparative Study on Korean and Japanese Traditional Furniture Design - Based on the residential behavior related to floor sitting.pdf. Asian Society for the Science of Design.

Melewar, T. C., Foroudi, P., Gupta, S., Kitchen, P. J., \& Foroudi, M. M. (2017). Integrating identity, strategy, and communications for trust, loyalty, and commitment. European Journal of Marketing, 51(3), 572-604. https://doi.org/10.1108/EJM-08-2015-0616

Ozdemir, S., Zhang, S. J., Gupta, S., \& Bebek, G. (2020). The effects of trust and peer influence on corporate brand-Consumer relationships and consumer loyalty. Journal of Business Research, 117, 791-805. https://doi.org/10.1016/j.jbusres.2020.02.027

Pallant, J., Sands, S., \& Karpen, I. (2020). Product customization: A profile of consumer demand. Journal of Retailing and Consumer Services, 54(September 2019), 102030. https://doi.org/10.1016/j.jretconser.2019.102030

Park, M., \& Yoo, J. (2018). Benefits of mass customized products: moderating role of product involvement and fashion innovativeness. Heliyon, 4(2), e00537. https://doi.org/10.1016/j.heliyon.2018.e00537

Shankar, V., Smith, A. K., \& Rangaswamy, A. (2003). Customer satisfaction and loyalty in online and offline environments. International Journal of Research in Marketing, 20(2), 153-175. https://doi.org/10.1016/S0167-8116(03)00016-8 
Supriadi, \& Putri, P. (2020). Jurnal Administrasi Bisnis Terapan. Jurnal Bisnis Terapan, 2(2), 130-137. Syahmardi, Y., Octavia, A., \& Oktaviani, E. (2017). Pengaruh Experiential Marketing Terhadap Customer Satisfaction dan Customer's Brand Loyalty Pizza Hut Kota Jambi. Prodising Seminar Nasional AIMI.

Tarafder, P. (Dr) N. (2019). Interior Design and Interior Decoration with Textiles. Journals of Mechatronics Machine Design and Manufacturing, 1(2).

Till, B. D., \& Busler, M. (2000). The match-up hypothesis: Physical attractiveness, expertise, and the role of fit on brand attitude purchase intent, and brand beliefs. Journal of Advertising, 29(3), X13. https://doi.org/10.1080/00913367.2000.10673613

Twyman, M., Harvey, N., \& Harries, C. (2008). Trust in motives, trust incompetence: Separate factors determining the effectiveness of risk communication. Judgment and Decision Making, 3(1), 111120. http://journal.sjdm.org/bb10/bb10.html

Van Rompay, T., \& Pruyn, A. (2008). Affective meaning integration in design and its influence on product and brand evaluation. Proceedings from the 6th Conference on Design and Emotion 2008, August.

Warayuanti, W., \& Suyanto, A. (2015). The Influence of Lifestyles and Consumers Attitudes on Product Purchasing Decision via Online Shopping in Indonesia. European Journal of Business and Management, 7(8), 74-80. https://www.iiste.org/Journals/index.php/EJBM/article/view/20944

Westall, M. (2012). Hello Kitty, Hello Art! Art Exhibition \& Book Launch Hits New York City's Openhouse Gallery. FAD Magazine.

Zhang, S., Xu, J., Gou, H., \& Tan, J. (2017). A Research Review on the Key Technologies of Intelligent Design for Customized Products. Engineering, 3(5), 631-640. https://doi.org/10.1016/J.ENG.2017.04.005 